\title{
Cyberbullying Among Urban Teens
}

\author{
Titis Pratitis Niken ${ }^{1 *}$, Suryanto Suryanto ${ }^{2}$, Mumtazah Miqdah ${ }^{3}$ \\ 1, 2, 317 Agustus 1945 University of Surabaya, Indonesia \\ *Corresponding author.Email:nikenpratitis@untag-sby.ac.id
}

\begin{abstract}
Cyberbullying is said to be a way of bullying in cyberspace, especially on social media. And the perpetrators are urban teenagers because of technological advances. Cyberbullying occurs because of the convenience in cyberspace, but in Indonesia, this case is still underestimated. Using Henry Tafjel's theory of social identity, there are three theories of social identification, social categorization, and social comparison. The methodology used is qualitative, with a descriptive research type and a genome- rology paradigm. The informants used two teenagers, with the type of informant above 17 years old and under 20 years old living in Surabaya. This research was conducted in Surabaya which was selected by snowball. Collecting data using inductive interviews and literature study. While the data analysis techniques used transcripts, data reduction, data presentation, and concluding.
\end{abstract}

Keywords: Cyberbullying, cyberspace, social media, urban teenagers, social identity

\section{INTRODUCTION}

Today, the most common case among urban adolescents is a case of bullying. According to Sejiwa (2008: 2), bullying is a situation where the abuse of power is carried out by a person/group. The rise of bullying cases has been in the spotlight from various circles, the phenomenon of bullying is starting to get more attention, because of the rampant impact that is generated and many harms various parties. Examples of bullying behaviour include mocking, spreading rumours, inciting, ostracizing, scaring (intimidation), threatening, bullying, resisting, or physically assaulting (pushing, slapping, or hitting).

Bullying behaviour such as hitting victims of bullying whose words are felt less pleasant and mocking or mocking victims of bullying at a high level means the bully as a step to become a "ruler" and as a process of self-discovery obtained from combining and integrating sources of meaning such as meeting basic needs, personal relationships, and fun activities (Shidiqi \&Suprapti, 2013).

Due to significant changes in technology, information can spread quickly to all circles. The Internet can make it easier for users to exchange information without having to face to face with each other. In addition, the existence of the internet also encourages the emergence of various social media such as Facebook, Twitter, Instagram, and so on. With the internet that is very advanced in this day and age, everyone can access a lot of information without filters, resulting in negative impacts, especially among teenagers who still cannot control themselves. Adolescents tend not to be able to sort out positive or negative activities. they are more easily influenced by the surrounding environment (Qomariyah, 2011).

In the development of information technology began rampant bullying behaviour on the internet or also called cyberbullying. intimidation that is carried out during cyberbullying is more directed at harassing the victim through technological devices. The forms and kinds of cyberbullying actions vary widely, ranging from uploading photos or making posts that embarrass victims, making fun of victims to accessing other people's social network accounts to threaten victims and create problems such as threats via e-mail and creating websites to spread slander, even to removing someone from a group in several social media groups.

The motivation of the culprit is also very diverse, sometimes just because of a fad or just a joke, wants to seek attention, there is also because of anger, frustration and want revenge, and there is also because of the environment of his peers, and more. Some of the things that distinguish bullying in general from cyberbullying are first, it can produce very rapid effects. Those who are physically engaged in physical bullying or are bullied frequently at school or elsewhere, or those who are not 
popular enough to engage in verbal bullying can now do so online without fear of reprisals (Hoobs, 2008). Second, cyberbullying makes its victims not easily go or run away from the perpetrator, in contrast to bullying in general. Although SMS messages can be deleted, teens tend to carry them wherever communication tools are. This makes it difficult for them to run away from cyberbullying actors. Cyberbullying is more secretive than bullying in general. Perpetrators are not aware of the direct impact their behaviour has on the victim. As a result, cyberbullying actors have a lower sense of empathy than those who do bullying directly (Steffegen and Konig, 2009). Perpetrators can harass their victims throughout the day for 24 hours. The anonymity inherent in any electronic communication model not only conveys identity but can reduce social accountability, making it easier for users to engage in aggressive adversary actions (Li, 2007).

The tools used to do cyberbullying according to Sheri Bauman (2008; in Sylmia, 2012) are Instant Message (IM), Chatroom, Trash Polling Site, Blog, Bluetooth bullying, and social networking sites. Bhat (2008; in Sylmia, 2012) in the Australian Journal of Guidance \&Counselling mentions one of the tools of cyberbullying is a mobile phone. The feature used in intimidating is sending text messages or SMS, images, or videos that disturb the victim.

Cyberbullying is easier to do than bullying in general because the perpetrator can do bullying without the need to face to face with others who are targeted. They can berate and easily intimidate their victims because they are behind a computer screen or staring at a mobile phone screen without having to see the consequences inflicted on the victim. It should be wary that this case of cyberbullying is very difficult to identify because the perpetrators are anonymous and rarely known. Adolescents who act as perpetrators have aggressive and intimidating characteristics. In contrast, in studies that have been done, it was concluded that adolescents who acted as victims had passive and defensive characteristics. Characteristics in perpetrators and victims reflect that cyberbullying does often occur even though it is not realized by both parties (Akbar, 2015).

The present paper addresses to which extent cyberbullying can become a form of social identity.

\section{THEORETICAL FRAMEWORK}

According to Tajfel (in Hogg and Abram, 1998), social identity is part of a person's self-concept derived from their knowledge of membership in a social group along with the value and emotional significance of that membership. Social identity is related to engagement, caring and also a sense of pride from membership in a particular group. Social identity theory itself states that identity is bound to classify group membership, "Social identity theory is intended to look at the psychology of social relationships between groups, group processes and social self" (Hogg et al, 2000).

Social identity theory generally addresses individual behaviour that reflects larger social units such as social groups, organizations, cultures, and social groups that are referenced to each individual's behaviour. This theory believes that what an individual perceives, thinks, and does is a manifestation of the collective values typically conserved in a particular social organization that the individual is a part of. Thus it can be concluded that social identity is part of an individual's self-concept derived from his knowledge during his or her time in a particular social group accompanied by the internalization of values, emotions, participation, caring and pride as a member of that group.

Tajfel and Turner in 1979 distinguished three basic component processes of social identity: social identification, social categorization, and social comparison.

\section{Social Identification}

Ellemers (1993) states that social identification refers to the degree to which a person defines themselves (and is seen by others) as a member of a particular social category. A person's position in the environment can be defined according to the "categorization" offered. When a person identifies strongly with their social group, they may feel compelled to act as a member of the group. The most important aspect of the identification process is that a person defines himself or herself as a member of a particular group. Ellemers \& Ouwerkerk (1999) add that identification is used to refer to feelings of affective commitment to the group (i.e. emotional component), rather than the possibility to distinguish between members on different social categories (cognitive components).

\section{Social Categorization}

Ellemers (1993) states that categorization indicates an individual's tendency to structure his or her social environment by forming groups or categories that are meaningful to the individual. Categorization serves to interpret the social environment simply, as a result of the process of categorization, certain values or stereotypes associated with the group can also come from individual members of that group as well. Categorization in social identity allows individuals to judge similarities on things that feel the same in a group (Tajfel \&Turner, in Hogg \&Vaughan, 2002). The existence of social categories leads to self-categorization. Self-categorization is the cognitive association of self with social categories (Burke $\&$ Stets, 1998) which is the spontaneous participation of an individual as a member of a group. 


\section{Social Comparison}

When a group feels better compared to other groups, this can lead to a positive social identity. Ellemers (1993). Social identity is formed through social comparison. Through social comparison, social identity is formed through the emphasis of differences on things that feel different in-group and out-group (Tajfel \& Turner, in Hogg \&Abrams, 1990). Social comparison in behaviour between groups, according to Tajfel (in Hogg, 2003), emphasizes the following:

a. Extreme assessments of out-groups, and minority or subdominant groups, showed more differentiation than the majority or dominant groups.

b. The existence of social comparisons emphasizes different behaviours between groups (intergroup differentiation).

c. Individuals who are in sub-dominant groups always raise their group's self-esteem (social identity), by lowering the degree of other groups.

In social identity theory, an individual is not considered one individual in his or her life. Individuals are part of a particular group both consciously and unconsciously. The concept of social identity is how a person is socially defined (Verkuyten, 2005).

\section{METHOD}

This research is qualitative. A qualitative research method is chosen because the phenomena presented in this study use inductive thinking logic, which takes the existing problems starting from the field and then explained them in theoretical generalization as the beginning of the formation of conclusions.

This study describes data descriptively that serves to answer several questions about the state of an object or a very subject in detail. The questions that arise in this type of research are related to what, who, why, where, when, and how on the object of the study. In this study, the selection of informants in this study using snowball retrieval techniques, the reason for taking informants with snowballs because this study did not know much about cyberbullying and in this study only got one key informant who had experienced cyberbullying problems.

From the information of the informant subject, the researcher will meet with the next informants who are following the criteria related to the focus of the problem on this study until the information that the researcher wants to know is fulfilled. For the process of retrieving data in this study took several informants who have the category of informants, namely informants aged between 17 - 20 years who live in Surabaya and perform cyberbullying actions or become cyberbullying actors.
The process of determining informants based on previous informants without determining the exact amount to dig up information related to the necessary research topics until data saturation is obtained. Data that has been collected through observations and in-depth interviews are then processed and classified in the same category. The classified data is then systematically explained based on each category and interpreted to the conclusion stage.

\section{DISCUSSION}

\subsection{Identification in Cyberbullying}

Based on the results of the study showed that identification was done because the perpetrators felt that the environment or group had advantages compared to the environment and outside groups. Identification is also done based on pride because it falls into the scope of the environment or group. The perpetrator sees similarities and feels that he belongs to the group and is subjectively proud of the group.

The most important aspect of the identification process is that a person defines himself or herself as a member of a particular group. In this case, as done by actors who identify themselves in an in-group environment they feel better than an out-group environment that is considered no better by cyberbullying. The perpetrators identified themselves in an in-group environment and began to commit cyberbullying actions that make fun of and blaspheme the environment that the perpetrator feels as an out-group.

\subsection{Social Comparison in Cyberbullying}

Social comparison is done because of the results of previous identification, the form of comparison is more comparing in a negative direction, namely making fun, dating, and seeing the lack of the two groups. The perpetrators make comparisons because it is considered to prove that the group occupied by the perpetrator has far-reaching advantages to make fun of and insult groups outside the group of perpetrators, and feel the group entered by the perpetrator is more proud and judged more subjectively. The social comparison also provides a negative stereotype against outgroups or comparison groups such as the comparison group arguably the ugliest or far-lost overall.

According to Hogg \& Abrams (1990), in social comparison, individuals seek to achieve a positive identity if individuals join the ingroup. The desire to achieve a positive identity in this social identity is a psychological movement of individual behaviour in the group. The process of social comparison makes a person get an assessment of the position and status of his group. Behaviour that emphasizes differences between the group it has (in-group) and other groups (out-group). 
Differences between groups will affect a person's perception of one's group and the other group.

\subsection{Forms of Cyberbullying}

The form of cyberbullying carried out by the perpetrator is flaming (burning) that is by provoking the emotions of the victim and makes the victim hot will bully a perpetrator so that there is a war of comments or sailing attacks in return. In all perpetrators perform cyberbullying actions with the same form that is flaming.

\subsection{Reactions Caused}

The reaction caused by victims from cyberbullying carried out by the perpetrators, namely there is a victim reaction that immediately replies, there is a silent victim reaction, there is a mutual backlash between both parties as obtained by some informants, and there are even those who even reply to their friends, namely friends of victims who even attack their victims. The reaction caused by victims of cyberbullying is related to social identity theory, namely the impact of social comparisons carried out. Social comparisons made by the perpetrators cause a reaction in the form of a reply that is by giving each other the advantages of each group, and there are also those who resigned to accept the comparison because it is in accordance with the facts.

\section{CONCLUSION}

Cyberbullying is a form of social identity, which is done to increase the prestige and strengthen the social identity of the perpetrator, cyberbullying is also used to bring down the social identity of the victim. Cyberbullying is done by the perpetrator only to raise the degree in his group by comparing and vilifying the group of victims in cyberspace.

The perpetrator identifies himself as being in the appropriate environment or group and begins cyberbullying to compare and prove his group is better than his victim group. The perpetrators also categorized which groups would be cyberbullying materials to compare which groups were best. Cyberbullying that occurs in urban adolescents is carried out by groups owned by perpetrators with victim groups. Comparison between groups is the reason for cyberbullying. Comparisons are done such as doing comparisons by looking for articles as evidence that the group of informants or perpetrators (in-group) is better than the group of victims (out-group) and send to groups or forums with harsh words, do comparisons directly by using harsh words against the group of victims (outgroup) because of very clear differences, make comparisons because they do not like the group of victims (out-groups) and use Rants in a post that exists in cyberspace and social media.
From the results of the cyberbullying carried out, according to the perpetrators, the perpetrators received various reactions from the victim group, such as victims who immediately retaliated against the perpetrator's actions, victims who did not respond to the perpetrator's actions, there were also victims who responded back with their friends, and some reciprocal between the two groups.

The first suggestion is given to parents to become a new discourse for the community, especially parents to know the association of the child, especially in cyberspace. Because so far many parents do not understand how to use the virtual world. So that children can do cyberbullying. And at least parents enrich their knowledge about cyberspace to protect their children from cyberbullying.

The next suggestion from now onwards is that people can realize that allowing or accepting cyberbullying behaviour in the social environment, it means giving bullies power to the cyberbullying perpetrators themselves and creating unhealthy social interactions and increasing culture of violence. The next suggestion is for researchers who want to suggest using a different theory or point of view so that they can explore the problem more deeply and can also give different results from what has been discussed in this study and previous research.

\section{REFERENCES}

[1] Baron, Robert A. \& Byrne, Donn. (2004). Psikologi Sosial. Jakarta: Erlangga

[2] Darma . Dkk. (2009). "Buku Pintar Menguasai Internet”. Jakarta: Mediakita

[3] Denzib Dan Lincon. (2009). Hand Book Of Qualitative Reaserch. Yogyakarta: Pustaka Pelajar.

[4] Hogg, Michael A \& Vaughan Graham M. (2002). Social Psychology. Third Edition. London: Prentice Hall, Pearson Education.

[5] Iskndar, (2008). Metodologi Pendidikan Dan Sosial (Kuantitatif Dan Kualitatif). Jakarta Garuda Persada Press.

[6] Johnson, D.W., F.P. Johnson. (1987). Joining Together : Group Theory and Group Skills. Ed ke3. Englewood Cliffs : Prentice Halls

[7] Moeleong, Lexy J. (1989). Metodologi Penelitian Kualitatif. Bandung: Pt. Remaja Rosdakarya

[8] Nasrullah, Rulli. (2015). Media Sosial. Bandung: PT Remaja Rosdakarya.

[9] Ramadhan, Arief. (2005). Seri Pelajaran Komputer Internet Dan Aplikasinya. Jakarta: Pt. Alex Media Komputindo. 
[10] Ritzer dan Goodman. (2004). Teori Sosiologi Modern. Jakarta: Kencana Perdana Media Group.

[11] Stangor, Charles. (2004). Social Group in Action and Interaction. New York : Psychology Press

[12] Yusuf LN, Syamsu. (2000). Psikologi Perkembangan Anak \& Remaja. Bandung: PT. Remaja Rosdakarya.

[13] Alam, Muhammad A. \&Prahastiwi Utari. (2015). Cyberbullying pada Media Sosial. Surakarta: Universitas Sebelas Maret

[14] Asie, Matraisa B. (2014). Studi Deskriptif Perilaku Bullying Pada Remaja. Surabaya: Universitas Surabaya

[15] Ellemers, Naomi. (1993). The Influence of Sociostructural Variables on Identity Management Strategies. European Review of Social Psychology.

[16] Emilia. \& Tino Leonardi. (2013). Hubungan antara Kompetensi Sosial dengan Perilaku Cyberbullying yang Dilakukan oleh Remaja Usia 15-17 Tahun. Surabaya: Universitas Airlangga

[17] Larasati, Ageng. (2016). Kecenderungan Perilaku Cyberbullying Ditinjau dari Traits Dalam Pendekatan Bigfive Personality pada Siswa Sekolah Menengah Atas Negeri di Kota Yogyakarta. Yogyakarta: Universitas Islam Negeri Sunan Kalijaga

[18] M Mawardah. MG Adiyanti. (2014). Regulasi Emosi dan Kelompok Teman Sebaya Pelaku Cyberbullying. Yogyakarta: Universitas Gadjah Mada

[19]Rifauddin, M. (2016). Fenomena cyberbullying pada remaja. Jurnal Ilmu Perpustakaan, Informasi, dan Kearsipan Khizanah Al-Hikmah, 4(1), 35-44

[20] Sejiwa. (2008). Bullying: Mengatasi Kekerasan di Sekolah dan Lingkungan Sekitar Anak. Jakarta: Grasindo.

[21] Shidiqi, Muhammad F. \& Veronika Suprapti. (2013). Pemaknaan Bullying pada Remaja Penindas (The Bully). Surabaya: Universitas Airlangga

[22] Jalil, A. (2015). Cyberbullying. Diakses melalui http://abduljalil.web.ugm.ac.id/2015/02/12/cyberbu llying/

[23] Widiatmoko. (2016). Kasus Cyber Bullying terhadap Remaja Cantik "Sonya Depari"(online).Dalam http://www.kompasiana.com/singgih_widiatmoko2 2/kasus-cyber-bullying-terhadap-remaja-cantiksonya-depari, diakses tanggal 13 Januari 2021 